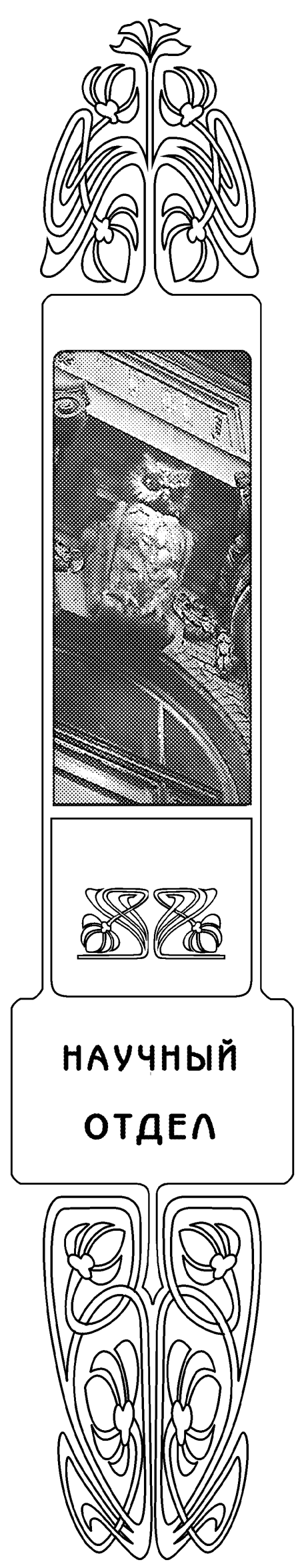

УДК 553.98

\title{
МИНЕРАЛЬНЫЕ АССОЦИАЦИИ ПРОДУКТОВ ГИДРОТЕРМАЛЬНОГО ИЗМЕНЕНИЯ - КЛЮЧ К ПОНИМАНИЮ ВОЗНИКНОВЕНИЯ ЗОН РАЗУПЛОТНЕНИЯ И ФАЗОВОЙ ЗОНАЛЬНОСТИ УГЛЕВОДОРОДОВ (на примере Западной Сибири)
}

\author{
А.Д.Коробов, Л.А.Коробова' \\ Саратовский государственный университет, \\ кафедра минерологии и петрографии, \\ ${ }^{1}$ кафедра геологии и геохимии горючих ископаемых \\ Отделение геологии НИИ ЕН СГУ \\ E-mail: korob@info.sgu.ru
}

Вопреки общепринятой катагенетической природе ломонтита из осадочных толщ доказано его гидротермально-метасоматическое происхождение в нижнемеловых терригенных отложениях, перекрывающих ископаемый континентальный рифт. В породах,испытавших низкотемпературную пропилитизацию,ломонтит является минералом-индикатором коллекторов, а кальцит-флюидоупоров. Установлено, что фазовая зональность нафтидов осадочных бассейнов с погребённым грабен-рифтом контролируется прогревом материнских толщ в процессе тектоногидротермальной активизации: газ $\left(330-280^{\circ} \mathrm{C}\right) \rightarrow$ газоконденсат $\left(280-200^{\circ} \mathrm{C}\right) \rightarrow$ нефть + + газоконденсат $\left(200-170^{\circ} \mathrm{C}\right) \rightarrow$ нефть $\left(170-60^{\circ} \mathrm{C}\right)$.

Mineral Association of Products of Hydrothermal Changing - Key to the Understanding of Origin of Loose Zones and Phase Zonation of Hydrocarbons (on the Example of West Siberia)

\section{A.D.Korobov, L.A.Korobova, E.F.Akhlestina}

In spite of the accepted katagenal laumontite nature from sedimentary strata, its hydrothermal metasomatic origin in lower-chalky terrigenous deposits, recovering mineral continental rift has been proved. In rocks undergoing propylization of lower temperature, laumontite is a mineral-indicator of containers and calcite-of screens. It is established that phase hydrocarbon zonation of sedimentary basins with buried rift is controlled by the heat of parental strata in the process of tectonichydrothermal activity: gas $\left(330-280^{\circ} \mathrm{C}\right)-$ gas condensate $\left(280-200^{\circ} \mathrm{C}\right)$-oil + gas condensate $\left(200-170^{\circ} \mathrm{C}\right)$ - oil $\left(170-60^{\circ} \mathrm{C}\right)$.

\section{Введение}

В последние годы все больше появляется данных об участии растворов различной природы в формировании коллекторов нефти и газа. Циркулирующие по ослабленным направлениям горячие воды участвуют в эпигенетическом минералообразовании, в частности приводят к возникновению цеолитов. В настоящее время известно, что цеолиты развиты достаточно широко в составе осадочных пород. Считается, что их происхождение связано главным образом с преобразованием пирокластического или иного силикатного материала в процессе диагенеза или катагенеза. Недостаточное внимание в данном вопросе уделяется наложенным гидротермальным преобразованиям.

Установлено, что для стадии начального катагенеза $\left(100 \pm 20^{\circ} \mathrm{C}\right)$ характерны анальцим, клиноптилолит, гейландит (как правило, господствует один из этих минералов), а для глубинного $\left(200 \pm 50^{\circ} \mathrm{C}\right)$ - ломонтит [1-3]. Вместе с тем в определенных геологических об- 
становках такая закономерность отсутствует или заметным образом видоизменяется. В частности, на платформах с погребенными рифтовыми мегапрогибами наблюдается крайняя неоднородность распространения цеолитов по латерали в осадочных толщах на близких глубинах. Так, в условиях Западно-Сибирской плиты цеолиты (ломонтит) обнаружены в терригенных породах на глубинах 3003,0-3018,0 м (скв. 300, Восточно-Уренгойская площадь), 3185,3-3195,4 м (скв. 2020Р, Пякяхинское газоконденсатное месторождение) и 3192,0-3201,0 м (скв. 2042, Хальмерпаютинское газоконденсатное месторождение Болшехетской синеклизы). Важно подчеркнуть, что ломонтит здесь ассоциирует с новообразованным эпидотом, хлоритом и гидрослюдами - типичными минералами пропилитов. Характерно, что перечисленные месторождения находятся в непосредственной близости от Колтогорско-Уренгойского грабенрифта [4]. В удаленных же от мегапрогиба районах метасоматические цеолиты, эпидот и гидрослюды в осадочных толщах не встречены.

Сказанное заставляет усомниться в только лишь катагенетической природе цеолитизации осадочных толщ и признать особое влияние погребенного палеорифта Западной Сибири на рассматриваемый процесс. Этот фактор почему-то игнорируется геологами. Между тем существенные аномалии теплового поля в ископаемых континентальных рифтах, обусловленные локальными неоднородностями земной коры и гидротермальными процессами в зонах разломов, могут сохраняться до 100 млн лет [5]. Вышеупомянутые гидротермальные процессы порождают флюидодинамические системы осадочных бассейнов, в которых, с одной стороны, рассеянное органическое вещество преобразуется в углеводороды (УВ) и приобретает способность мигрировать из нефтематеринских пород [6], а с другой - возникают разнотемпературные метасоматические формации. Неодинаковый прогрев нефтегазопроизводящих толщ горячими растворами, контролируемый положением ископаемых континентальных грабен-рифтов, может служить причиной фазовой зональности УВ. Так, на севере Западной Сибири с приближением к арктической акватории, куда раскрывается стержневой для региона Колтогорско-Уренгойский рифт, преобладают газовые и газоконденсатные месторождения, а на юге, в области замыкания грабен-рифта, - нефтяные.

Как известно, наиболее высокотемпературные (глубинные) метасоматические формации или зоны (на отметках свыше 3 км) представлены актинолитовой, эпидот-хлоритовой и пренитовой фациями; промежуточные зоны (от 1 до 3 км) - хлорит-альбитовой фацией; приповерхностные зоны (менее 1 км) - цеолитовой и трансильванской фациями. Среднетемпературная (хлорит-альбитовая) пропилитизация характеризуется появлением в метасоматитах равновесного парагенезиса альбит + эпидот + хлорит + пирит + + лейкоксен $[7,8]$. Низкотемпературная пропилитизация (без альбита, по Д.С. Коржинскому) подразделяется на цеолитовую (ломонтит, анальцим, вайракит, натролит + хлорит + адуляр + пирит) и трансильванскую (карбонат + иллит + хлорит + + селадонит + адуляр + пирит) $[9,10]$.

Из приведенной классификации видно четкое положение ломонтита, эпидота и других гидротермальных минералов в ряду метасоматических формаций. С этих позиций попробуем определить происхождение цеолитизации терригенных пород пласта БУ ${ }_{16}{ }^{0}$ скв. 2020Р Пякяхинского месторождения, делая акцент на взаимосвязь вторичных процессов в изверженных породах грабен-рифтов и сопряженных изолированных впадин и перекрывающих их осадочных образованиях. Это позволит сделать следующее: во-первых, совершенно по-новому взглянуть на природу вторичных изменений терригенных толщ Большехетской синеклизы, приводящих в одних случаях к разуплотнению, а в других - к переуплотнению пород, - выделить минералы-индикаторы скрытых на глубине разломов (зон повышенной проницаемости); во-вторых, провести сопоставление общепринятых понятий «катагенез», «апокатагенез» с конкретными температурными интервалами гидротермального процесса и на этой основе попытаться объяснить возникновение фазовой зональности углеводородов в пределах Западно-Сибирской плиты.

\section{Процессы преобразования терригенных пород}

Петрографические исследования керна Пякяхинского месторождения, отобранного из пласта БУ ${ }_{16}^{0}$ (заполярная свита, валанжинский ярус нижнего мела), показали, что песчаные алевролиты и песчаники испытали главным образом низкотемпературную пропилитизацию. Среди последней мы, в соответствии с теоретическими представлениями Д.С. Коржинского [7,8], М.А. Ратеева с коллегами [10] и В.И. Гугушвили [9], различаем цеолитовую и трансильванскую фации. Продукты среднетемпературной пропилитизации выражены слабо, но отмечаются во всех исследованных образцах. Рассмотрим подробнее каждую из них.

Среднетемпературная пропилитизация в породах пласта БУ ${ }_{16}^{0}$ проявилась, прежде всего, в развитии эпидота. Его количество ограничено. Он обнаруживает сонахождение с широким набором гидротермальных минералов: ломонтитом, хлоритом, кальцитом, кварцем, редко пиритом и гидрослюдой - и встречен во всех анализированных пробах. Эпидот тесно ассоциирует с хлоритом (и продуктами его позднего преобразования), иногда замещая его. Он часто развит в основной (цементирующей) массе терригенных пород, образуя достаточно крупные кристаллы. Обломки пород содержат новообразованные эпидот, хлорит и лейкоксен. При этом нередко наблюдается концентрация мелких выделений 
гидротермального эпидота вокруг частично или полностью эпидотизированных плагиоклазов. Зерна биотита в незначительной степени замещены эпидотом.Что касается другого характерного минерала среднетемпературных пропилитов альбита, то его сложно обнаружить. Связано это с тем, что в условиях слабого развития процесса формируется «аномальный», по В.Л. Русинову [11], альбит, диагностика которого затруднена. Поэтому минералом-индикатором среднетемпературной пропилитизации терригенных пород пласта БУ ${ }_{16}^{0}$ Пякяхинского месторождения является легко диагностируемый в шлифах эпидот. Специальные исследования, проведенные нами на Паужетском гидротермальном месторождении (Южная Камчатка), показали, что среднетемпературная пропилитизация развивается в интервале температур от 330 до $300-280^{\circ} \mathrm{C}$ [12].

Низкотемпературная цеолитовая пропилитизация проявлена наиболее широко на глубине 3189,40-3192,40 м и на глубине 3195,30 м (обр.

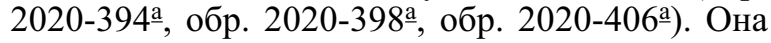
выражается в ломонтитизации различных ингредиентов породы и нередко накладывается на участки, испытавшие предварительную хлоритизацию, окварцевание, карбонатизацию, эпидотизацию, пиритизацию и лейкоксенизацию, т. е. среднетемпературную пропилитизацию.

Кальциевый ломонтит - индикаторный минерал цеолитовых пропилитов - тесно ассоциирует с хлоритом и продуктами его более позднего изменения. Поэтому в базисе терригенных пород, как правило, присутствует, по данным рентгенофазовых исследований, хлорит-цеолитовый (хлорит + + смешанослойный хлорит - монтмориллонит + + ломонтит) микроагрегат. При этом практически невозможно отличить реликты предшествующей хлоритизации от той, которая сопутствовала цеолитовой пропилитизации. Ломонтит образует пойкилобласты - крупные пластинчатые призматические кристаллы с совершенной спайностью в одном, редко двух, направлениях, в которые погружен обломочный материал. Пойкилобластическая ломонтитизация - характерная черта зон интенсивной цеолитовой пропилитизации.

Обломки пород и минералов в различной степени изменены. Полевые шпаты ломонтитизированы, пелитизированы, эпидотизированы, серицитизированы, хлоритизированы, редко соссюритизированы. Биотит значительно преобразован, причем в несколько этапов. Сначала он был эпидотизирован, лейкоксенизирован, а в самую позднюю (низкотемпературную) стадию - гидрослюдизирован, вермикулитизирован, гидратирован, смектитизирован.

Новообразованный пирит встречается в виде редких гнезд и рассеянных глобул. Он развит по биотиту, хлориту, обломкам эффузивных пород.

Еще одной характерной особенностью цеолитовых пропилитов является проницаемость. Пе- трографические наблюдения свидетельствуют, что сообщающиеся между собой поры составляют в среднем 6-10\% площади шлифа. Форма их неправильная, часто удлиненная. Размеры варьируют от 0,08 мм и 0,08 х 0,16 мм до 0,25 х 0,50 мм.

Низкотемпературная трансильванская пропилитизация встречена нами на глубине 3193,90 м (обр. 2020-402ㄹ). Наиболее ярко она проявилась в кальцитизации различных ингредиентов терригенных пород.

Кальцит ассоциирует с хлоритом, гидрослюдой и продуктами их низкотемпературного преобразования. Наиболее активно процесс проявился в цементирующей массе пород, где формировался различно окристаллизованный кальцит и возникали пойкилобласты этого минерала. Редко межзерновые зоны заполнены ломонтитом. Наблюдается это в том случае, если карбонатизация несколько ослабевает. На участках же активной кальцитизации ломонтит отсутствует.

В карбонатный цемент, часто представленный пойкилобластами кальцита, погружен обломочный материал. Обломки полевых шпатов и эффузивов, прежде в различной степени эпидотизированные, хлоритизированные, лейкоксенизированные, бывают значительно корродированны поздним карбонатом кальция или даже полностью замещены кальцитом.

На участках шлифа, где процесс проявлен наиболее активно, видны обломки кварца, корродированные кальцитом.

Еще одной особенностью трансильванских пропилитов является слабая их проницаемость. В шлифе не обнаружены какие-либо поры или каверны. От этого песчаник выглядит достаточно прочным и массивным.

Важно отметить, что характер карбонатизации терригенных пород удивительно напоминает особенности их цеолитизации. Протекая одновременно, эти два процесса вместе с тем пространственно не пересекаются. К такому же выводу мы пришли, изучая современные гидротермальные процессы на Камчатке. Там нами было установлено, что низкотемпературная пропилитизация развивается в интервале от 300-280 до $200^{\circ} \mathrm{C}$ [12].

Гидротермальная аргиллизация фиксируется в шлифах как самый поздний (низкотемпературный) процесс. Он затрагивает, прежде всего, слюды, хлорит и плагиоклазы. Биотит при этом гидратируется, гидрослюдизируется, вермикулитизируется, смектитизируется. Хлорит, согласно рентгенофазовых исследований*, замещается смешанослойными хлорит-смектитовыми образованиями, вплоть до формирования самостоятельного смектита (монтмориллонита). Плагиоклазы пелитизируются - мутнеют за счет развития глинистых минералов.

\footnotetext{
* Рентгенофазовые исследования проводились в ФГУП ВИМС (г.Москва) ведущим научным сотрудником, кандидатом геол.минерал. наук Г.К.Кривоконевой.
} 
Гидротермальная аргиллизация, как показали наши исследования на Паужетском месторождении горячих вод, протекает при температурах ниже $200^{\circ} \mathrm{C}$. Причем в интервале $200-150^{\circ} \mathrm{C}$ формируюся так называемые аргиллизированные пропилиты со смешанослойными образованиями, а в диапазоне $150-80^{\circ} \mathrm{C}$ - гидротермально-метасоматические глины (смектиты, каолинит) [12].

\section{Обсуждение результатов}

На примере Шаимского нефтегазоносного района (НГРН) нами установлено $[13,14]$, что характер эпигенетических изменений пород осадочного чехла Западно-Сибирской плиты контролируется разрывными нарушениями и определяется вспышками гидротермальной деятельности, которая сопровождала периоды тектонической перестройки региона.В течение мезозоя активизация Западно-Сибирской плиты возобновлялась неоднократно $[15,16]$. При тектоно-гидротермальной активизации эпицентры гидротермальных процессов были сосредоточены в погребенных грабен-рифтах и изолированных впадинах, порожденных раннемезозойским континентальным рифтогенезом [17]. Именно в толщах нижне- среднетриасовых изверженных пород, выполняющих наложенные на палеозойский фундамент структуры, зарождались и циркулировали горячие растворы, часть которых проникала в осадочный чехол по разломам.

Различия тектонических позиций грабенрифтов и генетически с ними связанных изолированных впадин определили специфику заполняющего их изверженного материала и постмагматических явлений, в данных структурах протекавших. Это касается гидротермальных процессов как доплитной стадии, так и тех, что сопровождали тектоническую активизацию уже сформировавшейся молодой платформы. В грабен-рифтах господствовало высокотемпературное, а в изолированных депрессиях - низкотемпературное гидротермально-метасоматическое минералообразование [13,14].

Что касается вулканогенных толщ структур активации, то одни авторы $[18,19]$ объединяют между собой породы, локализованные в изолированных депрессиях и мегапрогибах (в частности, Колтогорско-Уренгойском), относя их к породам туринской серии. Другие [20,21], напротив, дифференцируют их, считая, что в изолированных впадинах сосредоточены породы туринской, а в погребенных рифтовых грабенах - красноселькупской серии.

На примере Шаимского района, Широтного Приобья (Западно-Сибирская плита) и Урало-Тургайского региона установлена тождественность гидротермальных (гидротермальнометасоматических) изменений пород туринской серии и перекрывающих осадочных толщ вдоль рассекающих их одновозрастных разломов, возникших при позднеюрской тектоногидротермальной активизации. Преобразования связаны с появлением в тех и других породах структурно совершенного триклинного каолинита, диккита, накрита (редко) и рафинированного кварца $[14,22,23]$. Эти изменения контролируют, в частности, высокую продуктивность шеркалинской свиты в пределах Таллинского месторождения [24] и абалакской свиты (вогулкинская толща) в Шаимском районе [13]. Кроме того, прогрев осадочных пород циркулировавшими горячими растворами в период активизации серьезным образом повлиял на нефтеносность баженовской свиты [25].

Если распространить полученные закономерности на территорию Большехетской синеклизы (район Тазовской губы), где расположено Пякяхинское газоконденсатное месторождение, то необходимо связывать выявленную в пласте БУ ${ }_{16}^{0}$ пропилитизацию с аналогичными, но, вероятно, более интенсивными процессами в изверженном комплексе находящегося поблизости погребенного грабен-рифта. Сказанное полностью подтверждается соседством месторождения с Колтогорско-Уренгойским мегапрогибом, а также характером изменений нижне-среднетриасовых базальтов, вскрытых Тюменской сверхглубокой скважиной (СГ-6), заложенной в осевой зоне КолтогорскоУренгойского грабен-рифта [19]. Пробурена эта скважина в 60 км западнее г. Уренгой.

Анализ литературных материалов [18,26-30] и просмотр шлифов из коллекции В.В. Липатовой и Т.Ф.Букиной показали, что нижнесреднетриасовые базальты и их пирокластические аналоги, вскрытые скв. СГ-6, испытали интенсивную среднетемпературную и низкотемпературную пропилитизацию. Надо особо подчеркнуть, что эти процессы достигали своего максимума на доплитном (доюрском) этапе развития территории, когда имел место континентальный рифтогенез. После формирования осадочного чехла в периоды тектоногидротермальной активизации данные процессы неоднократно возобновлялись, но каждый раз протекали со все уменьшающейся интенсивностью [17].

Среднетемпературная пропилитизация (от 330 до $300-280^{\circ} \mathrm{C}$ ) [12] наиболее масштабно развита на глубинах 7206,5-6983,7 м, 6704,4-6691,1 м и 6646,9-6625,9 м. Она приурочена к миндалекаменным базальтам, зонам разуплотнения (повышенной трещиноватости) и характеризуется появлением эпидота, кварца, альбита, хлорита, в меньшей степени кальцита и слюд. В отдельных случаях формируются эпидозиты.

Низкотемпературная пропилитизация (от 300-280 до 200 C) [12] представлена двумя фациями: широко развитой цеолитовой и ограничен представленной трансильванской.

Цеолитовая пропилитизация наиболее активно себя проявила в интервалах 6904,0-6858,4 м; 6834,0-6795,0 м и 6619,4-6579,1 м, где возникают 
типичные цеолитолиты. Эпизодически пропилитизация отмечается на глубинах 6704,4-6681,6 м; 6635,8-6623,9 м и 6565,7-6555,7 м. Она также приурочена к миндалекаменным базальтам и проницаемым трещиноватым вулканитам. Типоморфными минералами являются кальциевый ломонтит, хлорит, кварц, гематит (не всегда), слюды (редко). В силу того что среднетемпературные и цеолитовая фации низкотемпературных пропилитов развиваются в зонах повышенной проницаемости, часто наблюдается наложение (телескопирование) вторых на первые как результат остывания гидротермальных растворов. В итоге появляется парастерезис (пространственное сонахождение разновременных (разнотемпературных) минералов) эпидота, альбита, ломонтита в измененных базальтах и основных по составу туфах.
Трансильванская пропилитизация отмечается на глубине 7310,0-7261,0 м, где развивается по эффузивам и вулканокластическим породам. Фрагментарно встречается в миндалекаменных базальтах в интервалах 7055,4-7067,1 м; 6847,06854,0 м; 6565,7-6579,1 м; 6533,0-6546,0 м. Процесс характеризуется появлением кальцита, хлорита, кварца, слюд. Иногда происходит наложение трансильванских пропилитов на среднетемпературные аналоги как отражение регрессивной направленности гидротермального процесса. Важно подчеркнуть, что в измененных базальтах и туфах скв. СГ-6 ломонтит и кальцит совместно как правило не встречаются. Это прекрасно подтверждается детальными рентгеноструктурными исследованиями, которые были проведены Ю.П.Казанским и его соавторами [27] и отражены в табл.1-3.

Таблица 1

Состав основной массы эффузивов, туфов и продуктов их изменения (скв. СГ-6 коротчаевской свиты) по данным рентгеновского анализа [27]

\begin{tabular}{|c|c|c|c|}
\hline $\begin{array}{c}\text { Номер } \\
\text { образца }\end{array}$ & Глубина, м & Часть породы & Фазовый состав \\
\hline 94096 & 6970 & Эффузив & $\begin{array}{c}\text { Кальцит, хлорит, кварц, гематит, плагиоклазы } \\
\text { (альбит, андезин), ломонтит (следы) }\end{array}$ \\
\hline 8715 & 6563 & Туф & $\begin{array}{c}\text { Кальцит, хлорит, кварц, гематит, плагиоклаз } \\
\text { (андезин) }\end{array}$ \\
\hline 9244 & 6849,2 & Кварц-эпидотовая порода & Кальцит, кварц, эпидот \\
\hline 9086 & 6700 & $\begin{array}{c}\text { Гематит-хлорит-цеолитовая по- } \\
\text { рода }\end{array}$ & Ломонтит, гематит, кварц (следы) \\
\hline 9400 & 6903,6 & То же & $\begin{array}{c}\text { Ломонтит, хлорит, диоктаэдрическая слюда, } \\
\text { гематит, кварц (следы), плагиоклаз }\end{array}$ \\
\hline
\end{tabular}

Таблица 2

Состав миндалин и включений в вулканогенных породах коротчаевской свиты скв. СГ-6 по данным рентгеновского анализа [27]

\begin{tabular}{|c|c|c|c|c|}
\hline $\begin{array}{c}\text { Номер } \\
\text { образца }\end{array}$ & Глубина, м & Порода & Тип и размер включений & Минералы \\
\hline 8830 & 6579,6 & Измененный туф & $\begin{array}{c}\text { Мелкие червеобразные, } \\
\text { белые }\end{array}$ & Ломонтит \\
\hline $8963 \mathrm{a}$ & 6638,6 & То же & $\begin{array}{c}\text { Амёбообразные, диаметр } \\
\text { до 20 мм }\end{array}$ & $\begin{array}{c}\text { Ломонтит, хлорит, кварц, слюда } \\
\text { (следы), плагиоклазы (следы) }\end{array}$ \\
\hline 89636 & 6638,6 & То же & $\begin{array}{c}\text { Округлые, с неровными } \\
\text { краями }\end{array}$ & Хлорит, кварц \\
\hline $9077 \mathrm{a}$ & 6796,7 & То же & Округлые, диаметр 2-5 мм & Гидрослюда (серицит) \\
\hline 90776 & 6796,7 & То же & Признаки на плоскостях & Ломонтит, хлорит (следы) \\
\hline $9178 \mathrm{a}$ & 6820,5 & То же & Округлые, вытянутые & $\begin{array}{c}\text { Хлорит, кварц, ломонтит (сле- } \\
\text { ды) }\end{array}$ \\
\hline 91786 & 6820,5 & То же & Округлые, вытянутые & Ломонтит, кварц \\
\hline 9244 & 6849,2 & То же & $\begin{array}{c}\text { Неправильной формы, } \\
\text { жилкообразные }\end{array}$ & Кальцит, кварц \\
\hline 9325 & 6885 & Измененный туф & Лучистые агрегаты в порах & Ломонтит, хлорит (следы) \\
\hline $9409 \mathrm{a}$ & 6970 & $\begin{array}{c}\text { Измененный } \\
\text { эффузив }\end{array}$ & $\begin{array}{c}\text { Неправильные, вытянутые, } \\
\text { округлые, диаметр 5-20 мм }\end{array}$ & $\begin{array}{c}\text { Кальцит, кварц, слюда, калие- } \\
\text { вые полевые шпаты }\end{array}$ \\
\hline
\end{tabular}


Состав отдельных участков в эпидот-кварцевой породе коротчаевской свиты скв. СГ-6 по данным рентгеновского анализа [27]

\begin{tabular}{|c|c|c|c|}
\hline $\begin{array}{c}\text { Номер об- } \\
\text { разца }\end{array}$ & Глубина, м & Часть породы & Фазовый состав \\
\hline 9481 а & 7007,6 & Зона эпидотизации & Эпидот, кварц, хлорит, ломонтит \\
\hline 94816 & 7007,6 & Зона окремнения & Кварц, хлорит (следы), ломонтит (следы) \\
\hline 9481 в & 7007,6 & Кристаллы в пустотах & $\begin{array}{c}\text { Кварц, хлорит (следы), эпидот (следы) } \\
\text { ломонтит (следы), плагиоклазы (следы) }\end{array}$ \\
\hline
\end{tabular}

Следовательно, две фации низкотемпературных пропилитов (трансильванская и цеолитовая) в гидротермальном процессе были пространственно разобщены. Аналогичная закономерность нами установлена в измененных терригенных породах пласта БУ ${ }_{16}^{0}$ Пякяхинского месторождения. Все это говорит о единстве эпигенетических преобразований в породах фундамента (переходного комплекса) и осадочного чехла Западно-Сибирской плиты, захваченных тектоногидротермальной активизацией.

Поскольку среди рассмотренных нами вторичных продуктов присутствуют пространственно разобщенные две фации низкотемпературных пропилитов, проанализируем условия смены кальциевого ломонтита (ведущего минерала цеолитовых пропилитов) кальцитом-типичным карбонатом трансильванских пропилитов. А.Л.Олби, Е-Ан.Зен [31], А.Б.Томпсон [32], а впоследствии М.Т.Мироненко и Г.Б.Наумов [33] показали, что смена кальцита ломонтитом через промежуточные ломонтит-кальцитовый и кальцит-ломонтитовый парагенезисы определяется падением парциального давления углекислоты в гидротермальном растворе. Иными словами, цеолитовые парагенизисы ограничиваются областью очень низких давлений $\mathrm{CO}_{2}$. Установлено, что содержание углекислоты в недрах гидротермальных систем зависит от фильтрационных особенностей пород. Оно минимально в породах с повышенными фильтрационными свойствами, которые наиболее водообильны. Там достигается самое низкое парциальное давление $\mathrm{CO}_{2}$, что благоприятствует формированию ломонтита. С другой стороны, на участках с низкими фильтрационными характеристиками, свойственными экранам, активно развивается кальцит.

Следовательно, при низкотемпературной пропилитизации ломонтит является минералом-индикатором коллекторов, а кальцитфлюидоупоров или участков слабой гидродинамической активности растворов. Это нами доказано на примере действующих гидротермальных систем Камчатки [12] и подтверждается исследованиями в Западной Сибири. Достаточно вспомнить, что наблюдаемая в шлифах открытая пористость цеолитизированных песчаников Пякяхинского месторождения составляет 6-10\%. В карбона- тизированных же аналогах пласта БУ ${ }_{16}^{0}$ (трансильванских пропилитах) пористость в шлифах не отмечается вообще. Это совпадает с данными Р.С. Сахибгареева [4], который описывает развитие цеолитов в песчаном водоносном коллекторе скв. 300 (инт. 3003,0 - 3018,0 м) на ВосточноУренгойской площади. Последняя находится в приразломной зоне Колтогорско-Уренгойского грабен-рифта, многократно активизированного в мезозое [15].

Установленная для терригенных пород связь вторичных процессов с фильтрационными характеристиками в полной мере справедлива и для изверженных образований - нижнесреднетриасовых базальтов Колтогорско- Уренгойского мегапрогиба. Так, по данным Т.В. Карасевой (Белоконь) с соавторами [34, 35] и Ю.А. Ехлакова с коллегами [26], из метасоматически измененных (эпидотизированных и ломонтитизированных) базальтов скв. СГ-6 в интервале 6622,0-6654,0 м получен приток низкоминерализованной воды (метан до 98\%) с высокой газонасыщенностью. Пропилитизированные базальты-коллекторы обладают пористостью до $15 \%$ и проницаемостью до $7 \times 10^{-3}$ мкм $^{2}$. Мы предполагаем, что в качестве флюидоупора в этом случае могут быть хлоритизированные и карбонатизированные базальты, залегающие на глубине 6579,0-6520,0 м [26], которые мы относим к трансильванским пропилитам. Важно подчеркнуть, что это первый случай, когда базальты нижнего-среднего триаса Западной Сибири выступают в роли коллекторов. Во многом схожую картину мы наблюдали на Камчатке на Паужетском месторождении горячих вод [12].

Выявленные закономерности имеют еще одно очень важное следствие. Цеолитовые пропилиты, развитые в потенциально продуктивных толщах, свидетельствуют о зонах повышенной проницаемости и могут являться индикаторами скрытых на глубине разломов. Специфика геологического строения осадочного чехла Западно-Сибирской плиты такова, что разрывные дислокации если и существуют, то обладают весьма незначительной амплитудой смещения и зачастую не поддаются картированию. В связи с этим изучение особенностей пропилитизации осадочных толщ в тесном сочетании с закартированными разрывными нарушениями представляет несомненный интерес. 
Выяснив специфику гидротермальных изменений в зонах развития разрывных дислокаций, можно решать и обратную задачу: по характеру взаимоотношений ломонтита и кальцита судить об интенсивности тектонических нарушений в районах погребенного континентального рифта. Необходимость таких исследований подтверждается тем, что роль разрывных нарушений при формировании и переформировании нефтяных и газовых залежей чрезвычайно велика. Кроме того, в процессе бурения в зонах повышенной проницаемости возникают технические осложнения: потеря бурового раствора, обрыв оборудования и многое другое. Следовательно, своевременное обнаружение ломонтита в шламе поможет избежать крупных аварий при строительстве скважин.

В заключение коротко остановимся на причинах разнотемпературного прогрева нефтегазоматеринских осадочных толщ флюидами погребенных рифтов и генетически с ними связанных изолированных впадин и роли данного обстоятельства на возникновение фазовой зональности УВ. Отправной позицией в этих рассуждениях будут два установленных факта. Первый: в грабен-рифтах на всех этапах тектонической жизни господствовали более высокотемпературные по сравнению с изолированными депрессиями гидротермально-метасоматические процессы. Второй: на плитном этапе в периоды тектоно-гидротермальной активизации происходили близкие по характеру гидротермальные изменения как в вулканогенных породах туринской серии, так и в перекрывающих осадочных толщах вдоль рассекающих их одновозрастных разломов $[13,14]$. Кроме того, надо учитывать, что различные группы углеводородов имеют неодинаковую термодинамическую устойчивость. Поэтому в соответствии с существовавшими в периоды тектоно-гидротермальной активизации палеотемпературными условиями недр произошло термофракционирование УВ. По теоретическим соображениям В.Ф.Ерофеева [36], наблюдаемая сейчас геотермическая зональность региона, запечатленная, как мы доказали, в минеральных ассоциациях продуктов вторичного изменения, отражает (при известном допущении) характер распределения тепловых полей в период формирования залежей углеводородов.

Специальные исследования свидетельствуют [13], что на нефтяных и нефтегазоконденсатных месторождениях Шаимского НГНР породы осадочного чехла, перекрывающие изолированные грабены с нижне-среднетриасовыми вулканитами, в различной степени гидротермально аргиллизированы (от 80 до $200^{\circ} \mathrm{C}$ ). На Пякяхинском и Хальмерпаютинском газоконденсатных месторождениях Большехетской синеклизы породы осадочного чехла, находящиеся в непосредственной близости от погребенного КолтогорскоУренгойского грабен-рифта, претерпели уже низкотемпературную пропилитизацию (от 200 до $\left.280-300^{\circ} \mathrm{C}\right)$. Если дальше следовать подобной логике, то основные газовые месторождения Западной Сибири должны быть сосредоточены в осадочных толщах, расположенных в пределах Колтогорско-Уренгойского рифта (или его аналога) и испытавших наибольший прогрев, т.е. как минимум, среднетемпературную пропилитизацию (от 280-300 до $330^{\circ} \mathrm{C}$ ).

Это полностью совпадает с наблюдениями О.В.Япаскурта [3], установившего, что в межзерновых промежутках юрских песчаников из Тюменской сверхглубокой скв. СГ-6 кристаллизуются аутигенные (в нашем понимании гидротермальные ) минералы: эпидот, альбит, хлорит, кварц, карбонаты.

Сказанное не противоречит представлениям К.Н.Кравченко, О.В.Ивановой, Ю.К.Бурлина и Б.А.Соколова [37] о том, что наикрупнейшие газовые скопления приурочены к внутренним срединным частям крупнорифтогенных арктических нафтидных бассейнов. В зонах уникального газонакопления, по их мнению, нижняя часть чехла, в которой сосредоточены основные материнские породы, глубоко погружена и интенсивно апокатагенетически преобразована. В свете предлагаемой нами модели «апокатагенез» К.Н.Кравченко и его коллег [37] соответствует, по меньшей мере, среднетемпературной пропилитизации. Последняя генерировала огромное количество «нижнего высокотемпературного газа», который, по мнению вышеуказанных авторов, выступал в роли поршня УВ смеси и осуществлял субвертикальную сквозьрезервуарную миграцию до надежных покрышек в верхней части чехла, где формировались промышленные залежи.

Из сказанного следует принципиальный вывод о том, что фазовая зональность нафтидов в осадочных бассейнах с погребенным континентальным рифтом контролируется прогревом материнских осадочных толщ в процессе тектоногидротермальной активизации: газ $\left(330-280^{\circ} \mathrm{C}\right) \rightarrow$ $\rightarrow$ газоконденсат $\left(280-200^{\circ} \mathrm{C}\right) \rightarrow$ нефть + газоконденсат $\left(200-170^{\circ} \mathrm{C}\right) \rightarrow$ нефть $\left(170-60^{\circ} \mathrm{C}\right)$.

\section{Заключение}

Приведенный материал позволяет сделать следующие выводы:

1. Терригенные породы пласта БУ ${ }_{16}{ }^{0}$ скв. 2020Р Пякяхинского месторождения (заполярная свита, валанжинский ярус нижнего мела) испытали гидротермально-метасоматические изменения, сопряженные с тектоногидротермальной активизацией, которая произошла в среднем мезозое.

2. Изменения выразились в пропилитизации, сменившейся гидротермальной аргиллизацией. Среди пропилитов выделены две группы: среднеи низкотемпературные.

Среднетемпературная пропилитизация (от 330 до $280^{\circ} \mathrm{C}$; характерный минерал эпидот) проявилась повсеместно, но довольно слабо. 
Низкотемпературная пропилитизация (от 280 до $200^{\circ} \mathrm{C}$ ) развита широко и представлена двумя фациями: цеолитовой и трансильванской. Фильтрационно-емкостные свойства пород контролируются развитием каждой из этих фаций. Цеолитовая пропилитизация (характерный минерал кальциевый ломонтит) активно проявлена и приурочена к зонам разуплотнения. Трансильванская пропилитизация (типичный минерал кальцит) пользуется ограниченным распространением и локализована в слабопроницаемых зонах или в местах ослабления гидродинамической активности растворов.

Гидротермальная аргиллизация (от 200 до $80^{\circ} \mathrm{C}$; характерные минералы: смешанослойные хлорит-смектиты (монтмориллонит) и иллитсмектиты (монтмориллонит)) затронула все породы и свидетельствует об остывании циркулировавших горячих растворов.

3. В породах, испытавших низкотемпературную пропилитизацию, ломонтит является минералом-индикатором коллекторов, а кальцит - флюидоупоров.

4. Цеолитовые пропилиты служат показателями скрытых на глубине разломов. Поэтому своевременное обнаружение ломонтита в шламе поможет избежать крупных аварий при строительстве скважин.

5. Фазовая зональность УВ в осадочных бассейнах с погребенным континентальным рифтом контролируется прогревом материнских толщ в процессе тектоно-гидротермальной активизации: газ $\left(330-280^{\circ} \mathrm{C}\right) \rightarrow$ газоконденсат $\left(280-200^{\circ} \mathrm{C}\right) \rightarrow$ нефть + + газоконденсат $\left(200-170^{\circ} \mathrm{C}\right) \rightarrow$ нефть $\left(170-60^{\circ} \mathrm{C}\right)$.

\section{Библиографический список}

1. Коссовская А.Г. Минералогия терригенного мезозойского комплекса Вилюйской впадины и Западного Верхоянья. М., 1962. 204 с.

2. Коссовская А.Г. Генетические типы цеолитов стратифицированных формаций // Литология и полезные ископаемые. 1975. №2. С.23-44.

3. Япаскурт О.В. Предметаморфические изменения осадочных пород в стратисфере: процессы и факторы. М., 1999. 259 c.

4. Сахибгареев Р.С. Вторичные изменения коллекторов в процессе формирования и разрушения нефтяных залежей. Л., 1989. 243 c.

5. Рамберг И., Морган П. Физическая характеристика и направление эволюции континентальных рифтов // 27-й Междунар. геолог. конгресс. Тектоника. М., 1984. Т.7. C.78-108.

6. Соколов Б.А., Абля Э.А. Флюидодинамическая модель нефтегазообразования. М., $1999.78 \mathrm{c}$.

7. Коржинский Д.С. Зависимость метаморфизма от глубинности вулканогенных формаций // Тр. лаборатории вулканологии. 1961. Вып.19. С.5-11.

8. Коржинский Д.С. Очерк метасоматических процессов // Основные проблемы в учении о магматогенных рудных месторождениях. М., 1953. С.332-452.
9. Гугушвили В.И. Поствулканический процесс и формирование месторождений полезных ископаемых в древних островных дугах и интрадуговых рифтах (на примере Аджаро-Триалетской зоны Кавказа). Тбилиси, 1980. $184 \mathrm{c}$.

10. Ратеев М.А., Градусов Б.П., Ильинская М.Н. Глинообразование при постмагматических изменениях андезито-базальтов силура Южного Урала // Литология и полезные ископаемые. 1972. №4. С.93-109.

11. Русинов В.Л. Альбитизация плагиоклазов в условиях приповерхностной пропилитизации (на примере Камчатки) // Метасоматизм и другие вопросы физико-химической петрологии. М., 1968. С.218-237.

12. Коробов А.Д., Гончаренко О.П., Главатских С.Ф. и $\partial p$. История гидротермального минералообразования Паужетского месторождения парогидротерм и палеогидротермальных систем района // Структура гидротермальной системы. М., 1993. С.88-120.

13. Коробов А.Д., Коробова Л.А., Киняева С.И. Гидротермальные процессы в палеорифтах Западной Сибири и их роль в формирорвании жильных ловушек УВ доюрского комплекса Шаимского района // Геология, геофизика и разработка нефтяных и газовых месторождений. 2004. № 12. C.63-72.

14. Коробов А.Д., Коробова Л.А. Гидротермальные процессы в погребенных палеорифтах Западной Сибири и их роль в доломитизации известняков и насыщении пород фундамента нефтью // Геология нефти и газа. 2005. №3. C.37-46.

15. Сурков В.С., Трофимук А.А., Жеро О.Г. и др. Триасовая рифтовая система Западно-Сибирской плиты, ее влияние на структуру и нефтегазоносность платформенного мезокайнозойского чехла // Геология и геофизика. 1982. №8. C.3-15.

16. Ян П.А., Бейзель А.Л., Вакуленко Л.Г., Бурлева О.В. Литологические признаки тектоно-климатических событий в бат-позднеюрской истории Западно-Сибирского седиментационного бассейна // Юрская система России: проблемы стратиграфии и палеогеографии. Ярославль, 2007. C. 266-268.

17. Казаков А.М., Могучева Н.К., Девятов В.П., Смирнов Л.В. Триасовая система в разрезе Тюменской сверхглубокой скважины СГ-6 (Уренгойский район, Западная Сибирь) // Геология и геофизика. 2000. Т.41, №3. С.318-326.

18. Коробов А.Д. Гидротермальный литогенез в областях наземного вулканизма. Автореф. дис... д-ра геол.-минерал. наук. М., 1995. 45 c.

19. Сурков В. С., Девятов В.П., Жеро О.Г. и др. Структура земной коры района Тюменской сверхглубокой скважины // Геология и геофизика. 1993. Т. 34, № 1. С.120-126.

20. Бочкарев В.С. Вулканогенные образования триаса Западной Сибири. // Триас Западной Сибири (материалы к стратиграфическому совещанию по мезозою ЗападноСибирской плиты). Новосибирск, 2001. С.70-79.

21. Нестеров И.И, Бочкарев В.С., Пуртова С.И. Уникальный разрез триаса Западной Сибири // Докл. РАН. 1995. T. 340, № 5. C. 659-663.

22. Лукьянова В.T. Эпигенетические изменения гидротермального типа в триас-юрской толще Карашиликской 
впадины // Литология и полезные ископаемые. 1982. №5. C. $43-56$.

23. Лукьянова В.Т., Голубева Н.П., Халезов А.Б. Каолинит и диккит в мезозойских впадинах Урало-Тургайской области // Литология и полезные ископаемые. 1982. № 3. C.66-79.

24. Зубков М.Ю., Дворак С.В., Романов Е.А., Чухланцева В.Я. Гидротермальные процессы в шеркалинской пачке Талинского месторождения (Западной Сибири) // Литология и полезные ископаемые. 1991. №3. С.122-132.

25. Краснов С.Г., Хуторской М.Д. О влиянии интрузий в фундаменте Западно-Сибирской плиты на нефтеносность баженовской свиты // Докл. АН СССР. 1978. Т.243, №4. C.995-997.

26. Ехлаков Ю.А., Угрюмов А.Н., Бочкарев В.С. Расчленение осадочно-вулканогенной толщи триаса (красноселькупская серия) в Тюменской сверхглубокой скважине // Триас Западной Сибири (материалы к стратиграфическому совещанию по мезозою Западно-Сибирской плиты). Новосибирск, 2001. С.32-48.

27. Казанский Ю.П., Мозгунова Е.В., Москвин В.И., Солотчина Э.П. Состав и строение триасовых вулканогенных отложений сверхглубокой скважины ТСГ-6 (Уренгойский район, Западная Сибирь) // Геология и геофизика. 1995. T. 36, № 6. C.157-164.

28. Казанский Ю.П., Солотчина Э.П., Казанский А.Ю., Москвин В.И. Измененные вулканические породы триаса и перми (?) в Тюменской сверхглубокой скважине // Тюменская сверхглубокая скважина (интервал 0-7502 м). Пермь, 1996. Вып. 4. С.135-145.

29. Угрюмов А.Н. Вторичные изменения вулканических пород красноселькупской серии в разрезе Тюменской сверхглубокой скважины (СГ-6) // Результаты бурения и исследования Тюменской сверхглубокой скважины. Пермь, 1995. С.41-43.
30. Угрюмов А.Н. Вторичные изменения вулканических пород красноселькупской серии в разрезе Тюменской сверхглубокой скважины (СГ-6) // Тюменская сверхглубокая скважина (интервал 0-7502 м). Пермь, 1996. Вып. 4. С.146-155.

31. Олби А.Л., Зен Е-Ан. Зависимость фаций цеолитов от химических потенциалов $\mathrm{CO}_{2}$ и $\mathrm{H}_{2} \mathrm{O} / /$ Очерки физикохимической петрологии: В 2 т. М., 1969. Т.1. С.37-54.

32. Thompson A.B. $\mathrm{Pco}_{2}$ in low-glade metamorphism; reolite, carbonate, clay mineral, prehnite relations in the system $\mathrm{CaO}$ $-\mathrm{Al}_{2} \mathrm{O}_{3}-\mathrm{SiO}_{2}-\mathrm{CO}_{2}-\mathrm{H}_{2} \mathrm{O} / /$ Contribs. Mineral. and Petrol. 1971. V.33, №2. P.145-161.

33. Мироненко М.В., Наумов Г.Б. Физико-химические условия образования ломонтита в углекислых гидротермальных системах // Геохимия. 1982. №4. С.597-602.

34. Карасева Т.В., Горбачева В.И., Келлер М.Б., Пономарева $B$. А. Основные научные результаты исследования Тюменской сверхглубокой скважины // Тюменская сверхглубокая скважина (интервал 0-7502 м). Результаты бурения и исследования. Пермь, 1996. Вып. 4. C.49-62.

35. Карасева Т.В. (Белоконь), Ехлаков Ю.А., Горбачев В.И. $u \partial p$. Эффективность глубокого и сверхглубокого параметрического бурения для оценки ресурсов углеводородов ниже освоенных глубин // Приоритетные направления поисков крупных и уникальных месторождений нефти и газа. М., 2004. С.164-169.

36. Ерофеев В.Ф. Геотермическая активность недр и размещение залежей углеводородов // Советская геология. 1970. № 11. С.142-147.

37. Кравченко К.Н., Иванова О.В., Бурлин Ю.К., Соколов Б.A. Нафтидное районирование арктических акваторий России и Аляски в связи с размещением и поисками уникальных месторождений нефти и газа // Геология, геофизика и разработка нефтяных месторождений. 2000. № 11. C.2-10.

\section{ВИДЫ ВЗАИМОДЕЙСТВИЯ “ФЛЮИД - ПОРОДА” В ПРОЦЕССЕ ЭВОЛЮЦИИ ГЕОГИДРОДИНАМИЧЕСКИХ СИСТЕМ ОСАДОЧНО-ПОРОДНЫХ БАССЕЙНОВ}

\section{К.А.Маврин}

Саратовский государственный университет, кафедра геологии и геохимии горючих ископаемых E-mail: kam@rambler.ru

В статье рассматриваются особенности взаимодействия подземных вод с горными породами, газами, органическим веществом, а также новообразованных углеводородных флюидов с породами и водами на разных стадиях эволюции осадочно-породных бассейнов и трансформации типов геогидродинамических систем (ГГДС).

Kinds of «Fluid - Massive Material» Interference in Process of Evolution of Geohydrodynamic Systems of Aqueous-rocky Draws

\section{K.A.Mavrin}

The article is about the peculiarities of interference of ground water with massive materials, gases, organic substances, as well as interference

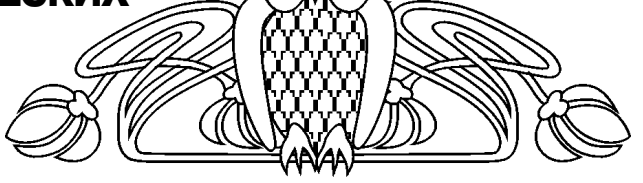

of new formations of hydrocarbon fluids with massive materials and waters on the different stages of evolution of aqueous-rocky draws and transformation of the types of geohydrodynamic systems.

Сложные процессы взаимодействия флюидной и породной составляющих земной коры изучены крайне недостаточно. Важно рассмотреть характер взаимодействия воды с горными породами, газами, органическим веществом, а также новообразованных углеводородных флюидов с породами и водами на разных этапах формирования осадочно-породных бассейнов. Понимая всю сложность рассматриваемой проблемы, мы преследуем цель вскрыть те возможности, которые открываются для её решения при рассмотрении трансформации типов геогидродинамических 